\title{
'Yo Te AMLO': Sentimentalism, threat and affective flows in political campaign song videos in Mexico
}

Media, Culture \& Society 202I, Vol. 43(3) 4II-427

(C) The Author(s) 2020

Article reuse guidelines: sagepub.com/journals-permissions DOI: 10.1 177/0163443720974248 journals.sagepub.com/home/mcs

(9SAGE

\author{
Andrew Green \\ University of Glasgow, UK
}

\begin{abstract}
Campaign song created as part of Mexico's 2018 national election, usually circulated as part of music videos, produced citizenship as intimate, sentimental, affectionate and partial. In music videos published online, often anonymously, musicians sought to develop affective links with political candidates, negotiating intimate pathways for the construction of democratic subjectivities. Such videos pose difficult questions for the notion of the rational, information-driven voter. In this article I take a partly ethnographic, partly analytical approach to explore the rich set of affordances these videos present for the construction of political coalitions within emerging democracies. Exploring Brian Massumi's theory of 'ontopower', I show how overlaps between threat and love served to heighten political indeterminacy, and demonstrate some of the perverse effects of this affective entanglement on the musicians involved. These videos, I highlight, raise questions about the power relations between political campaigns and audiovisual creativity in an increasingly rich media landscape.
\end{abstract}

\section{Keywords}

AMLO, campaign song, elections, Mexico, music videos, social media, threat

In Mexico, a combination of the widespread availability of recording technologies, online streaming platforms, and the country's transition to multiparty democracy since 2000 has led to the emergence of a seasonal industry in campaign song. Musicians can

\section{Corresponding author:}

Andrew Green, Leverhulme Early Career Research Fellow, University of Glasgow, 0/2, 96 Cartside Street, Glasgow G42 9TQ, UK.

Email: Andrew.green@glasgow.ac.uk 
often expect approaches by political parties offering to pay significant sums, dependent on their profile; an underground rapper I got to know was offered the equivalent of $\$ 1,500$ USD for a campaign song in 2018. Equally, advertising companies hired by political parties for electoral campaigns can devote much of their budget to creating original music, and accompanying videos. Campaign songs are recorded in diverse national and international popular genres, including corridos, reggaetón, rap, and son huasteco; during election season, one hears campaign songs frequently on public transport, and it is shared widely online, typically in music videos, especially on Facebook, Twitter, and YouTube. In recent years, campaign songs have become a subject of intrigue, written about in blogs and newspapers and discussed on television news; they are also a source of cultural intimacy (Herzfeld, 2001), an embarrassing reality of politics for many (especially middle-class) Mexicans.

Several factors make it difficult to estimate the reach of the Mexican campaign song economy. These include matters of definition, and the variety of platforms on which campaign song is shared. These complicating factors also reflect locally distinctive features of campaign songs, which are typically broadcast anonymously and removed from social media networks after elections are over. It is nonetheless clear that this is an extensive musical economy which reaches into the national and local arenas, and which is vital for many musicians' livelihoods. This is also an increasingly creative economy; where it previously tended to rework pre-existing tunes, contemporary campaign song in Mexico increasingly involves original compositions (Interview, Raúl, March 2020).

There is a long tradition in Mexico of using music as a vehicle for politically relevant messages and information, especially during conflict (cf. Westgate, 2013). Yet campaign songs are not, in general, used to communicate policy information. ${ }^{1}$ They tend to function in an affective, rather than 'modernist', manner (van Zoonen, 2005: 16), intervening in patterns of trust and mistrust in favour of particular politicians, and providing sonic branding for specific parties and politicians. The prevalence, and influence, of campaign song in Mexico thus raises questions about 'how music can animate or mobilize political participation' (Street, 2012: 78) - and the ways that musical-political intersections change over time, within evolving media and technological landscapes.

The use of popular song in electoral campaigns has been documented in contexts across the world (cf. De La Torre and Conaghan, 2009; Street, 2003), and through recent history, especially in the United States, where a decline in campaign song is noted in the twentieth century (Schoening and Kasper, 2011: 141-165; Scott, 2017). In recent years, scholars have tended to focus on the appropriation of music during electoral campaigns, complementing real-life trends, especially in the global North (Schoening and Kasper, 2011: 167ff). Yet campaign song has, in the scholarly literature, been paid surprisingly little attention given its prevalence, a situation Scott ascribes to liminality: US presidential campaign songs, for instance, 'are neither typically representative of commercial popular music, nor are they what most folksong researchers regard as folk music' (2017: 73). Campaign song, then, deserves attention in its own right, as an object for culturally situated analysis. In turn, contemporary Mexican campaign song is best interrogated as a rich, audiovisual medium mostly circulated within music videos. Recent research has highlighted the music video as a hybrid form, able to link cultural expressions on multiple scales and connect the global and local (Boxman-Shabtai, 2019; Ekdale, 2018); indeed, 
Richardson and Gorbman appeal to 'the explanatory value of boundary phenomena' (2013: 20) as a principle for research into the audiovisual. Listening attentively to contemporary campaign song invites us to explore how the multiscalar, hybrid music video format may constitute a resource for political coalition-building.

To study campaign song is also to question and provoke at the margins of politics in other ways; this genre often puts at stake key presumptions about electoral democracy. Van Zoonen (2005: 50-51), in exploring the use of music in electoral campaigns, suggests that 'concrete confrontations between popular music and politics [. . .] assume and reinforce the distinction between modern politics and entertainment as inequitable fields'. She highlights how political actors subordinate popular music to their own electoral interests while sidelining the forms of knowledge contained within popular songs and, frequently, the constituencies of fans they represent. Her account usefully highlights the fact that musicians whose songs are used for electoral politics are often comparatively disempowered in this process, little able to control the meanings attached to their work. Yet Van Zoonen focuses mostly on established democracies the United States and United Kingdom, at a time when it was still (however remotely) plausible to talk of politics as 'based on the ideals of an informed citizenry' (2005: 51). In Mexico, a new democracy in which a connection between politics and informed, 'rational' choice has never been hegemonic, amateur - or amateur-looking - music videos have become a key site for the staging of democracy (Strangelove, 2010: 190-191). This context points towards different questions: In democracies in transition, what emergent kinds of political subjectivities do music videos made for campaigns presume, establish, or explore? What, furthermore, is the relationship between such videos and the wider electoral campaigns they are created to support?

In this article, I want to demonstrate an 'affective attunement' between music and political campaigns during Mexico's 2018 elections, exploring how music videos made to promote political parties prompted voters 'to interpret situations by feeling like those directly experiencing them' (Papacharissi, 2014: 4, italics in original). I explore two intertwining feelings, threat and love, as central to these elections, aiming to demonstrate that music videos realized the affective discourses of campaign rhetoric in playful, unpredictable ways. There are two reasons that music videos can be considered particularly efficacious in this electoral landscape. The first is the rich set of audiovisual affordances presented by the music video format - referential, humorous, emotional, personal - which both complement the affective patterns of politics, and themselves birth anxieties about democracy in Mexico. The second is the mobility and interactivity of this format, in a country marked by high internet usage: music videos for political campaigns are often shared, reworked, and resignified. Indeed, it is for both of these reasons that such music videos cannot be said to be subordinate to politics in the way Van Zoonen suggests; in this article I will demonstrate instances of mobile, rich, unpredictable 'affective snowballing' (adapting Turino, 1999: 235) which drew the feelings of music videos beyond political actors' control.

The approach taken here combines analysis with ethnography. Between June 2018 and January 2020 I conducted nine months of ethnographic research, and carried out 12 in-depth interviews, with musicians and producers creating music videos for political campaigns. Equally, in the most high-profile cases the creators of campaign song videos 
are inaccessible, and I combine online research with analysis to map the affective 'connections, routes, and disjunctures' of campaign song (Stewart, 2007: 3).

\section{Affective flows: Threat and love}

During the campaigns for the national elections of July 2018, which was eventually won convincingly by Andrés Manuel López Obrador (most often called AMLO) and his recently created Movement of National Regeneration (Morena), the winners were supported by a wave of campaign song defending and advocating for AMLO as the object of their trust and affection. AMLO had run for president twice before 2018, representing the centre-left Party of the Democratic Revolution (PRD) in 2006 and 2012, and finishing second on both occasions. Both losses were controversial, mired in scandals to do with vote-buying, media bias, and electoral irregularities; they lent themselves to AMLO's self-portrayal as the popular, anti-establishment candidate. In the 2018 campaign, AMLO emphasized the threatened status of his political project, describing his opponents as an elite 'mafia of power' which would commit electoral fraud to thwart change; in response, he encouraged his supporters 'not to fear' (López Obrador, 2017). Equally, anticipating the criticism that his anti-establishment discourse was divisive, AMLO took on the mantra paz y amor ('peace and love', a phrase recalling the hippie movement [Hernández Borbolla, 2018; Zavaleta, 2018;]); some supporters, in turn, started to use the jocular hashtag \#amlove, and took to calling themselves 'Amlovers'. The affectionate mode of citizenship present within this juxtaposition between threat and love was key to the Morena campaign.

Recent scholarship has highlighted the increasing political importance of threat, a feeling of fear of an external agent. Threat engages in boundary work, but does so imaginatively, in relation to envisaged future antagonists, engaged simultaneously with temporality and exclusion. It motivates action; perceived threats against an individual's freedom to act often 'consume resources, divide attention [. . . ] and therefore disrupt and diminish an individual's mental activity', as well as provoking behaviours that contradict individuals' interests (Kayser et al. 2016: 2). Massumi's 2015 book Ontopower traces accelerating ways that power has come to be ordered around preemptive action responding to perceived threat. His starting-point is the logic of preemptive action established in the United States government's 'war on terror'. Preemption, for Massumi, is an 'operative logic of power' combining 'an ontology with an epistemology in such a way as to trace itself out as a self-propelling tendency' (2015: 5, italics in original). As action is increasingly structured around preemption, threat - with the 'status of indeterminate potentiality' (10) - embeds uncertainty into people's lives. Equally, for Massumi there is a clear relationship between threat and concentrated, unchecked power; the dynamics of threat have become familiar in the contemporary democratic retrenchment, as demagogues increase in power and influence.

Threat, then, is inevitably bound up in other affective assemblages, and conditions the ways that we are drawn to, or pushed away from, other individuals and groups. In this sense, threat is often vital to love. A number of scholars in literature and media studies have invoked the related concepts of 'threatened' or 'impossible' love (Kılıçbay and Incirlioğlu, 2003; Rutherford, 2014) to describe love that exists despite external threats 
to its existence; especially love defying societal norms, pressures, or boundaries. Stokes' (2010) discussion of citizenship in the music of Turkish singer Zeki Muren links 'impossible love' to Muren's queer identity, expressed in defiance of 'a paternalistic social order, and laboring heroically to bring into existence a set of relationships that are just, equitable, affectionate, and democratic' (69). The phrase describes, then, a form of love conditioned by threat, a feeling of simultaneous closeness and distance; a drawing of emotional boundaries, separating the threatened bond of love from some exterior antagonist. AMLO's embrace of a similar affective entanglement, which I will explore as threatened love, was evident in his dismissal of newspapers such as centre-right Reforma as part of the 'fifi ["elite"'] press'; in his suggestion that all those outside his Movement for National Regeneration were part of the 'mafia of power' (Alcantara, 2017); and in his repetition of the phrase 'peace and love'.

Other parties' campaign music played into this anti-establishment discourse. The most-heard song during the 2018 campaign (https:/www.youtube.com/ watch?v=Ti2pA5JgrMI) was a jingle over a cumbia rhythm, sung by a Wixárika child named Yuawi; it was made for Movimiento Ciudadano, a centre-left party in coalition with the right-wing National Action Party (PAN) and centre-left Party of the Democratic Revolution (PRD) (Beamonte, 2018; Movimiento Ciudadano, 2017). The jingle focused on the party, rather than personalities or policies, and it centred on a catchy, wordless syncopated hook, a written representation of which was subsequently incorporated into flashy visual advertising. The acoustic branding approach raised awareness of the party - the song went viral, having almost 60 million YouTube views at the time of writing but this did not translate into votes; Movimiento Ciudadano took under 5\% of the popular vote in the Senate. Indeed, such professional acoustic branding could serve as a focal point for criticism, especially concerning ethics and consent; satirical YouTube channel Política Piñata depicted the leader of the PAN-PRD-MC coalition, Ricardo Anaya Cortés, holding Yuawi hostage in his house and forcing the child to sing (Política Piñata, 2018). Such professional acoustic branding was counterproductive in another way, however: it suggested the polished, professional presentation of the PRI (Revolutionary Institutional Party) regime of Enrique Peña Nieto (2012-2018), seen as repressive and incompetent, which the Mexican electorate was about to reject.

Morena's campaign song videos drew a deliberate contrast with such efforts. It is true that, as a new party, Morena lacked the budget of established political parties, which were responsible for the vast majority of vote-buying in 2018 (Tourliere, 2018). The Morena campaign was, correspondingly, supported by hundreds of low-budget amateur music videos. Yet Morena also invested in professionally produced (and expensive) music videos made to look like amateur productions through, for example, deliberately reducing video quality (Interview, Moisés, January 2020). ${ }^{3}$ (Indeed, some contributors to the campaign song economy told me of suspicions that Morena had surreptitiously invested in amateur music videos in order to sidestep limits on campaign spending.) The Morena campaign's anti-establishment message was thus communicated not only in language but through the strategies by which the campaign was mediatized. Especially interesting, and consequential, were interactions between amateur and professional proMorena music videos - and the ways that each shaped expectations and possibilities for the other. These videos extended Morena's campaign discourse, vouching for AMLO as 
a trustworthy, affable individual, and dramatizing perceived threats against him. Correspondingly, they became a focal point for unanticipated reactions which, as they entangled the auditory, visual, textual, asnd affective, brought into dialogue various responses to AMLO's campaign: adulation, criticism, mockery, fear. In the remainder of this article, I explore the affective flows of threatened love in two pro-Morena music videos known, in turn, as 'La Niña Bien' and 'Yo Te AMLO'.

\section{'No me apures, neta, no me censures': How not to be a 'good girl'}

One of the most influential music videos of the campaign came to be known 'La Niña Bien' (The Good Girl, https://www.youtube.com/watch?v=6szGBQWAQFY), released in support of AMLO's Morena party in March 2018. This video - accompanying a reggaetón song with visual humour - attracted much press and social media attention, some of it focusing on controversies surrounding its creation. Yet it was also effective at painting criticism of Morena as threatening to individual expressive identity, and led to other parties responding with their own music videos.

The video opens with a young female protagonist, identified as 'Almudena Ortíz Monasterio' (2018) (an upper-class-sounding name later revealed to be false), driving in an Audi convertible through an upper-class neighbourhood to a church whilst a reggaetón beat sounds in the background. A florid font both reveals her name and falsely suggests that the video was created for an assignment at Jesuit University of Guadalajara entitled 'Contemporary Problems of Mexico'. Inside, while she takes communion from the priest, the opening verse resembles a confession: 'Father, you'll say I'm crazy, but something got into me, and the heart doesn't lie'. The confession presents an internalized drama: 'I know I've sinned', sings the Niña Bien, 'I have thousands of doubts, I don't know what to do'. The opening verse thus contains a double meaning indexing the reggaetón trope of possession by a beat: in the line 'something got hold of me', the urge to vote Morena is elided with the urge to dance. This drama is heightened by the music: the lyric comes at an early point in the song, where a reggaetón beat is hinted at but not yet fully formed.

As the beat arrives, at thirty seconds into the video, the Niña Bien starts to dance at the altar, and unties her hair. The priest, robed, joins in, as she declares her intentions in the song's chorus: 'Although I'm a good girl, I'm going to vote for you-know-who/Hear me, please, we're going to change our country's destiny'. Two things are especially notable here: first, the song's use of an English loan word, please, to indicate that the song's protagonist is upper-class; second, the appearance of the phrase ya sabes quien ('youknow-who'), a term commonly used to refer to AMLO by his supporters which figured support for the candidate as a subversive sentiment that one might wish to suppress.

We are then shown a shot of her concerned-looking parents, as she sings 'Father [papi, a term with sexual connotations within reggaetón] I don't want to offend you or anything, but today's job is to get rid of the PRI'. Her father, red-faced, drags her out by the arm from the church, as she sings 'don't rush me, seriously, don't shut me up [no me apures, neta, no me censures]'. This performance of music as 'a means by which we announce our liberty' soon crosses into the apparently 'trivial and inconsequential', 
traversing multiple registers of censorship (Street, 2012: 10): the Niña Bien visits the gym (wearing an outfit in the colours of the Mexican flag), drives around a posh neighbourhood and - in a note of humour - matches with AMLO on Tinder. As she drives, she pre-empts recriminations for her political views: 'I hope they don't change my Audi for a Chevy'. Voting for Morena is recognized as an act of bravery, in a conservative upperclass society, during an intervention by the priest, who raps to the Niña Bien ninety seconds into the video: 'Say it, Almudena, don't be ashamed/you should shout it, you should post it [that is, on Facebook], tell everyone without fear who your vote is for'. Of course, the priest's injunction to resist fear heightens and draws attention to the same. The video closes with a climactic demonstration of collective empowerment: the song's chorus returns as the church's congregation and choir dance to the beat, singing the song's optimistic message of national transformation.

Perceived threats are at play throughout the video: in the Niña Bien's fear of being silenced, in her physical removal from the church, in her fears of having her car - paid for by her wealthy parents - downgraded. Even the song's title implies the threat of censorship: we imagine a paternalistic authority figure telling us that 'good girls' don't vote that way. Equally, the video plays with the theme of love, directed towards the figure of AMLO, as the song takes on some of the romantic tropes of reggaetón. In performing the prohibition of love for AMLO, the video is exploiting reactant (Brehm, 1989) responses in order to make that possibility seem appealing. The Niña Bien's self-knowledge - her ironic attraction to AMLO - is reinforced by perceived threats against the full expression of her feelings, and the assertion that her 'heart doesn't lie'. Finally, the narrative of the video - a woman becoming physically liberated as she makes the empowering decision to defy social pressure and vote for AMLO - is also reflected in music. The song plays out over a familiar reggaetón beat whose underlying four-chord progression (VI-IV-I-V, identical to that of Luis Fonsi and Daddy Yankee's international hit 'Despacito'), beginning on a minor chord away from the tonic 'home' key, constantly forestalls a sense of closure, dramatizing the postponed desire of the video.

'La Niña Bien' was made with humorous intent, and was easy to dismiss. Some commentators focused on the true identity of Ortíz Monasterio, later revealed to be a model named Paulina Laborie, and the fact that the producers failed to inform the priest of the church in which the video was shot about their true purposes. The video also drew the ire of Catholic groups, causing Morena's campaign leadership to distance themselves from the video. Others dismissed 'La Niña Bien' as ineffective; the good thing, stated rightwing journalist Ricardo Alemán (later fired from a string of media posts after appearing to call on Twitter for AMLO's assassination) was that 'only a few simpletons swallowed it up' (2018). On their comedy show ¿Que Importa?, meanwhile, Jorge Ramón Sancristobal and Eduardo Videgaray cracked double entendres about the Niña Bien video's effects on their political awareness: 'It made our concern for politics really firm up' (Imagen Noticias, 2018).

Yet despite dismissals in the press, the video proved successful at provoking, and defining the terms of, subsequent musical exchange. In late March 2018, the satirical website El Privilegio de Mandar satirized the 'Niña Bien' video in a sketch showing Ricardo Anaya Cortés panicking over the video's effectiveness (El Privilegio de Mandar, 2018). Music videos from other parties soon emerged that responded, directly or 
indirectly, to 'La Niña Bien'; all depicted people defying their socio-economic position to vote for a certain candidate. The PAN responded first, with a reggaetón song entitled 'Chavo Chaka' (https://www.youtube.com/watch?v=m3A-czGJKo4) (a slang phrase denoting a young, image-obsessed, gym-going male from Mexico City's lower-class fringes) which depicted a twentysomething man from a poor neighbourhood on the outskirts of Mexico City deciding to vote for them, rather than for Morena (El Financiero Bloomberg, 2018). The PRI followed with 'La Chaira Arrepentida' (https://www.youtube. com/watch? $\mathrm{v}=\mathrm{GVwhBzVnh8Q}$ ), a music video about a university student defying her friends to vote for PRI candidate José Antonio Meade as 'the most responsible option'; frequently used as an insult against Morena supporters, the term chairo denoted a leftleaning voter concerned with social equality.

These videos, nonetheless, either failed to respond to the 'Niña Bien' video's discourse of threatened love, or helped to establish it further. For example, following the romantic overtones of the 'Niña Bien' video, the Chaira Arrepentida fixates on a photo of Meade, comically drawing attention to the rash covering much of his face: 'I'm going to vote for the one who has vitiligo'. Yet in the video, her pro-Morena friends are depicted in a positive light, expressing differences of opinion through song without appearing overly aggressive; her change of political affiliation thus threatens none of the negative social consequences of the 'Niña Bien' video. In many ways, meanwhile, the PAN's 'Chavo Chaka' video responds effectively to the 'Niña Bien', presenting a similar form of playful class reversal. Humour is found, for instance, in the scenery - in a comic contrast with the upper-class neighbourhood of the 'Niña Bien' video, the Chavo Chaka sings from the gym, a pesero (a cheap, small bus), a call centre, and a multi-storey car park; it is also found in the Chavo Chaka's poor attempts to speak English and French (which, in a touch of self-deprecating humour, mimics PAN leader Anaya Cortés' own much-mocked attempts to do so).

The problem is, however, that this protagonist pursues the Niña Bien with a threatening persistence. The video opens with the Niña Bien rejecting the amorous advances of our lower-class protagonist over the phone, but the Chavo Chaka is undeterred; conflating her abandonment of him with her abandonment of the PAN, he sings back that 'you're mistaken, Almudena, it's not my barrio [neighbourhood] you long for, what you want are my kisses, my heat [. . .] I know you love me, that I'm the one for you'. Towards the end of the video, the Chavo Chaka changes tack, trying to unveil the Niña Bien's true lower-class status: 'I know your car is rented and your hair has extensions, you're not guera [light-skinned] nor slim, and your travel pictures are photoshopped' - at this point the Niña Bien is pictured in front of red-brick buildings in a lower-class neighbourhood - 'but you have my love, just as you are'. Not only, then, does the video's avatar for the PAN repeatedly make unwanted amorous advances, but he concludes by threatening to 'out' the Niña Bien, and reveal to the world that the upper-class identity she is so concerned to maintain is fraudulent. As such, this video unwittingly entrenches further the narrative of threat presented in the video it intends to counter.

Occurring within two months, this exchange between music videos involved dynamic, intertextual play on musical, visual and narrative levels; equally, these affective exchanges proceeded on the basis of misdirection as much as understanding. Threat and love interplay here in subtly contrasting ways. We note the contrast between the threatened love of 
the Niña Bien and Chavo Chaka videos: while the former video conjures up an operative logic in which love is constituted by threat - we are drawn towards 'you-know-who' precisely by the performed unspeakability of his name - in the latter, love is threatened by its own object. Finally, it was the slipperiness and uncertainty pertaining to the pre-emptive logic of the Niña Bien video which made responding to it effectively such a challenge (Massumi, 2015: 9). Because threat here was never explicitly materialized, the epistemological grounds on which the initial claim to feeling threatened was based could never be challenged. Threat, insofar as it served as a locus of the indeterminate and the unknowable, was a source of power. As I will show in the next two sections, however, channelling such indeterminacy into politics was a difficult process to control.

\section{Yo Te AMLO}

In June 2018, a music video was circulated on YouTube entitled 'Que salgan los corazones a la calle' ('May hearts come out onto the streets', https://www.youtube.com/ watch? $\mathrm{v}=\mathrm{TDPB} 040 \mathrm{mfoc}$ ), and accompanied by the hashtag \#YoTeAMLO, a play on the Spanish phrase for 'I love you' in which the first-person singular 'love' (amo) is replaced by the candidate's acronym. Soon known simply as 'Yo Te AMLO', it was the project of Fernando Rivera Calderón, a well-known writer, comedian, musician, and television presenter who wrote the lyrics and convinced a number of high-profile friends - including singer and actress Regina Orozco, flautist Horacio Franco, actress Marisol Gasé, and Santa Sabina bassist Poncho Figueroa - to take part. The celebrity backing for 'Yo Te AMLO' drew comparisons to 'We Are The World', and the song garnered much press attention, with the hashtag \#YoTeAMLO becoming a Twitter trending topic. One Twitter user was even inspired by this hashtag to post a piece of revised Spanish grammar: yo te amlo [I love you], tu me amlas [you love me], nos amlamos [we love each other] (Cafeleería, 2018).

Rivera Calderón distanced 'Yo Te AMLO' from paid-for party-political propaganda, emphasizing that he had received no money to make the video. While some Morena staff - working for candidate for Secretary of Culture Alejandra Frausto - contributed to filming, they were not paid a fee; monetary transactions, Rivera Calderón told me, would have removed the video's 'weight' (Interview, August 2019). 'Yo Te AMLO' notably lacks the production values of the 'Niña Bien' video, fitting instead within a campaign song ecology dominated by sincere amateur productions.

The video opens with a scene of an open-air market, or tianguis, where sellers are sweeping the street and transporting goods to sell. As the bustling sound of the market cuts out, we hear the opening of the song: a rhythmic, syncopated, and elaborate solo played on a Baroque recorder by Horacio Franco, accompanied by a son jarocho rhythm played on the acoustic guitar. The video cuts back to the tianguis, where a group is gathered around Franco playing his recorder, as what was initially a non-diegetic sound is transformed into a diegetic one. We follow this group - several of whom are holding musical instruments - as they dance through the tianguis, before the video shows us Rivera Calderón singing the opening lines into a microphone: 'May hearts come out onto the streets/may those who love our country, come'. The song then sees a change in tone which establishes its emotional range: the line 'and without losing our memories/let's 
change history', alluding to Mexico's autocratic past, accompanies the first appearance of a minor chord in the accompaniment, as the song alternates between the major subdominant and the minor mediant.

The beat then emerges fully with a return to the tonic, as Rivera Calderón sings 'may those who before were silent, speak/they can't shut us all up with one finger' [that is, by raising a finger to their lips]; here the video shows a joyful gathering in the middle of the street, with the overlooking balconies full of revellers singing and dancing. As the descents from sub-dominant to minor mediant return, this gesture of censorship becomes one of defiance: the lyrics tell us that 'they've taken away so much from us/that they've taken away our fear'. A cadence transitions through major and minor sub-dominant followed by dominant as the music swells towards the chorus with the syncopated line 'we're all made of the same maíz'. The chorus, returning to the tonic, provides a narrative of shared optimism surviving against the odds: 'And hope is not exhausted/and the joy does not turn cold/and although the future is uncertain/we want to see a new day'. The second half of the chorus then concretizes the threat to freedom implied in the first half: 'And the love for our people/our land, our dreams/leaves us no longer indifferent/ your freedom has no owner'.

With the concluding line of the chorus the song breaks into an electric guitar solo, and we are shown couples dancing in the middle of the tianguis, before the musical accompaniment gives way to Regina Orozco reprising, a capella, the song's opening refrain. This serves as a prelude to the video's climax: the song works through an initially slow, accelerating waltz rhythm in triple metre, accompanied by a accordion solo in the norteño style. The song's backing then regularizes into a repeating harmonic sequence reminiscent of rock; the rhythm becomes faster and more intense. Only in the song's final few bars is a party-political stance revealed, as the cast chant the hashtag 'Yo Te AMLO' (I [Am]love you). Here the beat intensifies, in a performance of the breaking through of repression, as the video presents footage of participants singing; a scene intended to symbolize unity, joy, and liberation.

The response to the video drew out differing views of the role of sentimentalism in politics. Although some commentators dismissed 'Yo Te AMLO' as cursi ('corny'), the author and musician embraced such sentimentalism, framing the song as an effort to move towards a more tender, respectful, affectionate form of political campaigning: 'I felt that this campaign was very aggressive, that the messages being sent out are full of hate and of fear; [the song] shows another side of the country, a bit of the joy, and the desire to dance and sing' (Grupo Fórmula, 2018). Equally, the song was, according to Rivera Calderón, deliberately released towards the end of the campaign so as to influence undecided voters (Interview, August 2019). It strategically intervened, then, in an anti-Morena discourse alleging that AMLO was using coarse and dismissive language to accentuate political division.

Equally, the collectivity presented in the video was consequential for the message it sought to convey. Rather than engaging playfully with social divisions, like the 'Niña Bien' video, 'Yo Te AMLO' looks to bracket social class; its participants express their hope for change through shared, participatory music-making. The eclecticism of the song sends its own message: in the description accompanying the original YouTube video, Rivera Calderón explained that 'I wanted this to be a musical journey through the 
whole country, from son jarocho to ranchera music, baroque music [a reference to Franco's flute-playing], rock, and norteño music'. 'Yo Te AMLO' seeks to unify Mexico through the staging of musical difference, a gesture that recalls the cultural policy of the post-revolutionary state (Velázquez and Vaughan, 2006); as Rivera Calderon put it in the video's description, 'we have to learn [. . .] to leave space for all of the different Mexicos that we are'.

Yet while the 'love' of the song most closely resembles a spirit of optimistic collectivity, this love is lived in relation to an undefined external antagonist; shared sentimentalism is produced by gestures towards censorship and loss of freedom. Just as in the 'Niña Bien' video, then, love here both responds to the repressive regimes of the past, and constitutes an act of pre-emption, in ways that echo AMLO's campaign rhetoric.

\section{Austerity and mistrust}

After AMLO won the election in July 2018, Morena implemented the programme of cuts it had promised in order to combat corruption in government. The most high-profile features of this programme were cuts to politicians' salaries, the sale of the presidential jet, and the converting of the presidential residence, Los Pinos, into a free-to-access museum. In practice, however, the austerity programme of the Morena government threatened state cultural funding for some of the artists who had supported its campaign. AMLO's campaign had sent out conflicting signals about funding for the arts. At points, 'culture' was put forward as a solution to problems of crime and corruption. Indeed, in the notes underneath the original 'Yo Te AMLO' video Rivera Calderón had praised Morena's cultural policy as 'the most structured and inclusive' on offer at the 2018 election. Yet it was never clear what constituted 'culture' for the party's politicians, and the populism of the Morena campaign pointed towards a view of culture 'from below' (cf. Green, 2019) - that is, valuing 'popular' cultural practices that would exist irrespective of state funding. Soon after coming to power in December 2018, the new Morena government targeted the arts sector for funding cuts; in particular, large cuts were made to the budget of Fonca (National Fund for Culture and the Arts), with one prominent Morena politician stating that their grants for artists ought to be removed entirely. Several of the most well-known artists from the video were in receipt of, or had previously been awarded, Fonca grants, including Franco, Orozco, and Gasé.

In part, Fonca was targeted because of allegations of corruption and amiguismo ['networking'] that predated the Morena government. It was an unsympathetic institution to many: despite changes in its institutional priorities it continued to support mostly elite cultural activities; and it had been created under single-party rule, to foment legitimacy in the wake of the 1988 electoral fraud (Ejéa Mendoza, 2011). In August 2018, journalists analysed the institution's publicly available data and alleged patterns of corruption in the distribution of Fonca grants, showing that 'the probability of winning the grant for any applicant was $6 \%$, but $71 \%$ of those who had conflicts of interest [that is, personal connections to a jury member] won' (López San Martín, 2018). In an interview, meanwhile, a respondent who had previously worked at Fonca defended the institution, attributing conflicts of interest to the small size of the artistic community, and portraying Fonca as an example of artistic autonomy (Bourdieu, 1996: 47-112); its procedures of 
rotating juries and recusal for conflicts of interest, and the fact that its juries were populated by artists rather than politicians, made it comparatively resistant to corruption (Interview, Hugo, July 2019). Fonca became a divisive issue: in June 2019, as the Secretary of Culture arrived at the Ariel film awards, a protester held up a sign reading 'Citizens need arts, not crafts' [Ciudadanxs necesitan artes, no artesanías] (Huerta Ortíz, 2019). Built on problematic value judgements about cultural labour - breaking down along ethnicity and class lines, as 'crafts' were typically made by indigenous people such gestures only underlined state cultural institutions' challenges in forging a sense of purpose in a post-authoritarian society.

Some of the participants in 'Yo Te AMLO' - among whom several had received Fonca grants - were now placed in opposition to the new government's policies, narrated as part of the same corrupt 'mafia of power' that Morena saw themselves as opposing. In June 2019, Franco criticized the cuts, stating that 'as artists we can't survive without those grants'. Now he defended artists as a group from the dismissive language used by AMLO: 'We aren't fifis, we're workers as well [. . .] [Morena] were going to be inclusive, they have to be, from the President downwards' (de Ávila, 2019). Ricardo Alemán's new website La Otra Opinión noted Franco's comments as evidence that participants in 'Yo Te AMLO' regretted their vote - referencing the phrase chairos arrepentidos ('regretful chairos') to recall the anti-Morena campaign song (La Otra Opinión, 2019). While Franco's comments did not imply that he no longer supported Morena, they highlighted the risks of marshalling threatened love in support of a political party.

In turn, what had been sold as a movement of electoral insurrection was now tasked with governing. AMLO's political opponents were quick to concede the election, but subsequently used this as an opportunity to attack him; the fact that they could give 'loser's consent' (Anderson, 2007) so quickly while he had held mass demonstrations to protest alleged fraud in the 2006 election was alleged to exemplify a lack of fitness for democratic office. Other patterns of threat began to be emphasized: it was easier than ever to frame expressions of love for AMLO as a sign of a dictatorial personality cult. In this context, Rivera Calderón complained to me that since releasing 'Yo Te AMLO' he had suffered continuous online abuse (Interview, August 2019).

These dynamics came to the fore in 2019, when 'Yo Te AMLO' was recirculated online. On 12 June 2019 a Twitter site called Literal México posted the video with a description saying that the song 'will be circulated on social networks, media, and events related to López Obrador' (literalméxico, 2019). This post contained only the video's final thirty seconds in which the singers present their climactic declaration of love, omitting its allusion to an antagonistic, threatening political establishment. Literal México (2019) presented the video as new, implying that it had been created by Morena with public money. The reaction to the video cemented this falsehood: opponents of the Morena government painted the video as evidence of a 'messianic cult' (Ileana Mex, 2019). A right-wing Venezuelan website used 'Yo Te AMLO' to compare AMLO with Hugo Chávez, while criticising the Mexican president's musical taste - wrongly suggesting that he had personally overseen the video's creation (Cedrom, 2019). In response, some Twitter users pointed out that the video had been created for the 2018 election (ChumelTorres, 2019). Horacio Franco, again, publicly defended his participation in the 
video: 'the only thing I expressed was how sick I was of out-of-control corruption and the under-the-table authoritarian and dictatorial regime' (HoracioFranco, 2019). Franco's defence, then, involved both distancing himself from the new government and re-establishing within the conversation the antagonist which Literal México had removed.

These experiences demonstrated the divisive multiple trajectories of threat, whose perception depended on positionality, and relied on acts of pre-emption and imagination in which 'the object of power' was, in the main, 'formless and contentless' (Massumi, 2015: 175). The change of government ironically demonstrated that unifying 'culture' was no substitute for the politics of competing interests; as a video emphasizing a message of love became a locus of suspicion, some of those who made it found themselves on the wrong end of political division.

\section{Concluding remarks: On censorship and threat}

Such analysis suggests complex interconnections and mutual dependencies between threatened love and the more all-encompassing notion of censorship. Both videos analysed here, in different ways, used threats of censorship to evade dialogue; to create a self-completing and 'self-abstracting' (Massumi, 2015: 183) narrative. They both employed operative logic, using the threat of having their political views suppressed to lend those views greater weight. Threatened love, as narrated in campaign song videos, personalised the notion of censorship; in doing so, it imaginatively projected the dynamics of electoral politics into relationships of kinship and companionship. The threat of being silenced had the additional operative feature of heightening the importance of speech. To combine threat with censorship is to reckon with a more messy, rhizomatic version of music censorship: one that takes into account censorship as it unfolds in acts of embodiment, performance, and denunciation; as a notion emergent in its being invoked. Equally, the perverse outcome of the electoral campaign for some of those who participated in 'Yo Te AMLO' was envisaged in the unknowability that was inherent to the original gesture of threatened love. Where the 'Niña Bien' video had exploited the indeterminacy of threat to evade criticism, the sincere and inclusive threatened love of 'Yo Te AMLO' had more ambivalent effects for its creators.

In suggesting that music and politics be viewed as 'extensions of each other', Street has called for attention to locations in which 'music forms a site of public deliberation' (2012: 1, 8). Campaign song videos here emerged, I want to suggest, as one of the spheres in which the affective patterns of 'mainstream' electoral politics were most fully realized. Threatened love was made 'ordinary', in the sense of connecting 'public feelings that begin and end in broad circulation' with 'seemingly intimate lives' (Stewart, 2007: 2), through the affective labour of videos like the 'Niña Bien'. Equally, 'Yo Te AMLO' potentiated something else: a form of loving, affectionate citizenship tending towards the transcendent, a rupture with the ordinary in which its dismissal as 'sentimental' was rooted. As these songs functioned as a popular means of engaging voters with politics, they exerted influence both in political framing itself, and in the ways that established political frames came to be perceived.

It is not fair to say that politics hierarchically subordinated campaign song videos to its ends; to understand the relationship between the two, we ought to pay attention to the 
entanglements between them, and the nuanced, specific interventions made into these entanglements. Political power resided in the kinds of affective attunements demonstrated here between campaign rhetoric and pro-Morena music videos, but it also lay in the ability, after the campaign, to disrupt, attack or terminate such attunements. These disruptions starkly laid out musicians' disempowerment in relation to the political process, yet they also highlighted a wider crisis of agency: in an increasingly varied, fasting-moving media landscape, campaign song videos move far beyond the control of organized politics.

\section{Acknowledgements}

The author wishes to thank named and unnamed participants in this research, and Simran Singh and Matt Brennan for comments on earlier drafts of this article.

\section{Funding}

The author disclosed receipt of the following financial support for the research, authorship, and/or publication of this article: The research for this article was completed with the generous support of the Leverhulme Trust.

\section{ORCID iD}

Andrew Green (iD https://orcid.org/0000-0003-0643-6182

\section{Notes}

1. Although the prevalence of campaign song might suggest a substitute for written communication, in fact Mexico's literacy rate is relatively high (cf. Strangelove, 2010: 192-193).

2. Juan Ignacio Zavala defines fifis as 'people who have studied abroad, mostly; for some reason they don't participate in political parties, but opted for the media instead' (author's translation). https://elfinanciero.com.mx/opinion/juan-ignacio-zavala/la-guerra-contra-los-fifi (accessed 28-11-19).

3. Note: some names have been changed for this article.

\section{References}

Alcantara S (2017, August 21) Quien no se una con Morena es parte de la mafia del poder: AMLO. El Universal Queretaro. Available at: http://www.eluniversalqueretaro.mx/nacion/21-08-2017/ quien-no-se-une-morena-esta-con-la-mafia-del-poder-amlo

Ortíz Monasterio A (2018, March 18) Almudena Ortiz Monasterio - Niña Bien (Video Completo Original). Available at: https://www.youtube.com/watch?v=VI6g9QDT8KE

Anderson C (2007) Losers' Consent: Elections and Democratic Legitimacy. Oxford: Oxford University Press.

López Obrador AM (2017, June 30) Spot: Mándalos por un tubo. Available at: https://www.youtube.com/watch?v=Zoqob5eoOu8

de Ávila JJ (2019, June 6) Horacio Franco: Los artistas no podemos sobrevivir sin las becas del Fonca. El Universal. Available at: https://www.eluniversal.com.mx/cultura/horacio-francolos-artistas-no-podemos-sobrevivir-sin-las-becas-del-fonca

Beamonte P (2018, January 13.) ¿Quién es Yuawi, el niño que protagoniza el vídeo de Movimiento Naranja? Hipertextual. Available at: https:/hipertextual.com/juno/quien-es-yuawi-nino-queprotagoniza-video-movimiento-naranja 
Brehm JW (1989) Psychological reactance: theory and applications. In: Srull TK (ed.) NA Advances in Consumer Research, vol. 16. Provo, UT: Association for Consumer Research, pp.72-75.

Bourdieu P (1996) The Rules of Art. Cambridge: Polity Press.

Boxman-Shabtai L (2019) The practice of parodying: YouTube as a hybrid field of cultural production. Media, Culture \& Society 41(1): 3-20.

Cafeleería (2018, July 3) Yo te amlo, Tu me amlas, Nos amlamos. Available at: https://twitter. com/Cafeleeria/status/1014328934908026883

Cedrom (2019, June 13) o Te AMLO" el hit del momento en México. Venezuela Al Día. Available at: https://venezuelaaldia.com/2019/06/13/te-amlo-hit-del-momento-mexico/

ChumelTorres (2019, June 13) Eso del "Yo te AMLO" fue para la campaña, amigos. Qué puto oso, sí, pero ya había pasado. Y qué puto oso. Eso sí. Available at: https://twitter.com/ ChumelTorres/status/1139340739773493249

De la Torre C and Conaghan C (2009) The hybrid campaign: Tradition and modernity in Ecuador's 2006 presidential election. The International Journal of Press/Politics 14(3): 335-352.

Ejéa Mendoza T (2011) Poder y creación artística en México: Un análisis del Fondo Nacional para la Cultura y las Artes (FONCA). Mexico City: Universidad Autónoma Metropolitana, Unidad Azcapotzalco.

Ekdale B (2018) Global frictions and the production of locality in Kenya's music video industry. Media, Culture \& Society 40(2): 211-227.

El Financiero Bloomberg (2018, April 10) 'Chavo chaka', el panista que responde a la 'Niña bien'. Available at: https://www.youtube.com/watch?v=DVpX9AAhGEM

El Privilegio de Mandar (2018, March 27) Todo mal con la Niña Bien. Available at: https://www. youtube.com/watch?v=5dx9EXYg2zY

Green A (2019) 'What will the respectable public say?': protest musicianship and class in Sexta events in Mexico City. In: Montero Díaz F and Winter F (eds) Citizenship in the Latin American Upper and Middle Classes. London: Routledge, pp. 30-45.

Grupo Fórmula (2018, June 6) "Yo te AMLO" puede ser cursi, pero refleja alegría y no fue pagada: Rivera Calderón. Available at: https://www.youtube.com/watch?v=fXfutftAYhQ

Hernández Borbolla M (2018, November 16) 'Chairos' contra 'fifís': La polarización política que evidencia la lucha de clases en México. Available at: https://actualidad.rt.com/ actualidad/295880-chairos-fifis-polarizacion-politica-mexico

Herzfeld M (2001) Cultural Intimacy: Social Poetics in the Nation-State. Abingdon: Routledge.

HoracioFranco (2019, July 2) Con o sin gobiernos mi carrera se ha sostenido incorruptible por 41 años. Por mis principios no he sido lambiscón de ningún gobierno. A los anteriores no los apoyé y sin embargo me dieron trabajo. No persigo nada con apoyar a @lopezobrador_Solo confío en que su proyecto ayudará. Available at: https://twitter.com/HoracioFranco/status/1146275377314181121

Huerta Ortiz C (2019, June 25) Protestan frente a Frausto en el Ariel. El Universal. Available at: https://www.eluniversal.com.mx/espectaculos/cine/protestan-frente-frausto-en-el-ariel

Ileana_Mex (2019, June 13) No señores, la canción YO TE AMLO no es igual a la de Salinas. Entiendo su manía patética de defender lo indefendible culpando al pasado. Pero esta mamarrachada es culto al mesías. Así como en las sectas. Así como se comportan. Available at: https://twitter.com/ileana_Mex/status/1139161504220139520

Kılıçbay B and İncirlioğlu EO (2003) Interrupted happiness: class boundaries and the 'impossible love' in Turkish melodrama. Ephemera 3(3): 236-249.

Imagen Noticias (2018, April 11) Le aparece un 'Chaka' a la 'Niña Bien'. Available at: https:// www.youtube.com/watch?v=VD-snQnn0SQ 
Kayser DN, Graupmann V, Fryer JW, et al. (2016) Threat to freedom and the detrimental effect of avoidance goal frames: reactance as a mediating variable. Frontiers in Psychology 7: 632.

La Otra Opinión (2019, June 13) Chairos arrepentidos: compositores de \#YoTeAMLO se arrepienten de su voto. La Otra Opinión. Available at: https://www.laotraopinion.com.mx/chairosarrepentidos-compositores-de-yoteamlo-se-arrepienten-de-su-voto/

Garza Treviño L (2018, April 17) Lety Garza Treviño - No Somos Ovejas. Available at: https:// www.youtube.com/watch?v=QuMGwHGC7B4

Literal México (2019, June 12) Canción “YO TE AMLO”. Será difundida en redes sociales, en medios de comunicación y en eventos que tengan relación con@lopezobrador. Available at https://twitter.com/literalmexico/status/1138944249326686210

López San Martín M (2018, August 31) ¿Becas salpicadas de corrupción? El Heraldo de México. Available at: https://heraldodemexico.com.mx/opinion/becas-salpicadas-de-corrupciondefiniciones/

Massumi B (2015) Ontopower: War, Powers, and the State of Perception. Durham, NC: Duke University Press.

Movimiento Ciudadano (2017, December 18) Movimiento Naranja - Yuawi - Movimiento Ciudadano. Available at: https://www.youtube.com/watch?v=Ti2pA5JgrMI

Papacharissi Z (2014) Affective Publics: Sentiment, Technology, and Politics. New York: Oxford University Press.

Política Piñata (2018, May 2) Movimiento Naranja - Yuawi. Available at: https://www.youtube. $\mathrm{com} /$ watch? $\mathrm{v}=\mathrm{MmIZSMx} 3 \mathrm{oJ} 8$

Richardson J and Gorbman C (2013) Introduction. In: Richardson J, Gorbman C and Vernallis C (eds.) The Oxford Handbook of New Audiovisual Aesthetics. Oxford: Oxford University Press, pp.3-35.

Rutherford E (2014) Impossible love and Victorian values: JA Symonds and the intellectual history of homosexuality. Journal of the History of Ideas 75(4): 605-627.

Schoening BS and Kasper ET (2011) Don't Stop Thinking about the Music: The Politics of Songs and Musicians in Presidential Campaigns. Plymouth: Lexington Books.

Scott DB (2017) The US Presidential campaign songster, 1840-1900. In Watt P, Scott DB and Spedding P (eds.) Cheap Print and Popular Song in the Nineteenth Century: A Cultural History of the Songster. Cambridge: Cambridge University Press, pp.73-90.

Stewart K (2007) Ordinary Affects. Durham, NC: Duke University Press.

Strangelove M (2010) Watching YouTube: Extraordinary Videos by Ordinary People. London: University of Toronto Press.

Street J (2003) 'Fight the power': The politics of music and the music of politics. Government and Opposition 38(1): 113-130.

Street J (2012) Music and Politics. Cambridge: Polity Press.

Stokes M (2010) The Republic of Love: Cultural Intimacy in Turkish Popular Music. Chicago: University of Chicago Press.

Tourliere M (2018, June 27) Partidos intentaron comprar 30 millones de votos; 5.3 millones aceptaron por 500 pesos: Acción Ciudadana. Proceso. Available at: https://www.proceso. com.mx/540425/partidos-intentaron-comprar-30-millones-de-votos-5-3-millones-aceptaronpor-500-pesos-accion-ciudadana

Turino T (1999) Signs of imagination, identity, and experience: A Peircian semiotic theory for music. Ethnomusicology 43(2): 221-255.

Velázquez M and Vaughan MK (2006) Mestizaje and musical nationalism in Mexico. In: Vaughan MK and Lewis S (eds) The Eagle and the Virgin: Nation and Cultural Revolution in Mexico, 1920-1940. Durham: Duke University Press, pp. 95-118. 
van Zoonen L (2005) Entertaining the Citizen: When Politics and Popular Culture Converge. Oxford: Rowman \& Littlefield.

Westgate CJ (2013) Notes on the wire: Ballads, biases, and borders of performance journalism. Media, Culture \& Society 35(8): 996-1010.

Zavaleta N (2018, June 6) AMLO renta el Estadio Azteca a Televisa para su cierre de campaña; le pidió “amor y paz" a Claudio X. González. Available at: https://www.proceso.com. $\mathrm{mx} / 537359$ /amlo-renta-el-estadio-azteca-a-televisa-para-su-cierre-de-campana-le-pidioamor-y-paz-a-claudio-x-gonzalez 